\title{
Impact of Alkyl Spacer Length on Aggregation Pathways in Kinetically Controlled Supramolecular Polymerization
}

Soichiro Ogi, Vladimir Stepanenko, Johannes Thein, and Frank Würthner*

Universität Würzburg, Institut für Organische Chemie and Center for Nanosystems Chemistry, Am Hubland, 97074 Würzburg, Germany

KEYWORDS: Supramolecular polymer, Perylene bisimide, Off-pathway aggregate, Organogelator, Seeded polymerization

wuerthner@chemie.uni-wuerzburg.de

\section{Table of contents}

1. General

2. Synthesis and characterization of PBI derivatives

3. ${ }^{1} \mathrm{H}$ NMR spectra of monomeric ref-C2 and PBI-1-C4

4. Energy minimized structures of PBI derivatives

5. Analysis of self-assembly behavior of PBI-1-C4

6. References page $\mathrm{S} 2$

page $\mathrm{S} 3$

page $\mathrm{S} 8$

page $\mathrm{S} 10$

page $\mathrm{S} 11$

page S16 


\section{General}

Solvents and reagents were purchased from commercial suppliers and used without further purification, unless otherwise noted. Spectroscopic measurements were conducted under ambient conditions using dry solvents. Nuclear magnetic resonance (NMR) spectra were recorded on a Bruker Avance III HD (400 MHz) spectrometer. Chemical shifts are reported in parts per million (ppm) from tetramethylsilane $\left(0 \mathrm{ppm}\right.$ for $\left.{ }^{1} \mathrm{H}\right)$ or residual $\mathrm{CHCl}_{3}(77 \mathrm{ppm}$ for ${ }^{13} \mathrm{C}$ ) as the internal standard. UV/vis absorption spectra were recorded on a V-670 spectrophotometer equipped with a PAC-743R Auto Peltier 6/8-cell changer for temperature control. Atomic force microscopy (AFM) measurements were performed at ambient conditions with a Bruker AXS MultiMode ${ }^{\mathrm{TM}} 8$ SPM system and Solver Next system from NT-MDT in semicontact mode. Silicon cantilevers (OMCL-AC160TS, Olympus) with a resonance frequency of $\sim 300 \mathrm{kHz}$ and spring constant of $\sim 42 \mathrm{Nm}^{-1}$ were used. Scanning electron microscopy (SEM) measurements were performed with a Zeiss Ultra plus field emission scanning electron microscope. Images of the sample were taken using the SEM operated at $1.5 \mathrm{kV}$ with an aperture size set to $30 \mu \mathrm{m}$ to avoid excessive charging and radiation damage of the areas imaged. Fourier transform infrared (FT-IR) spectroscopic analysis was performed on a Jasco FT/IR-430 Spectrometer using a Beckmann Quick-mount IR Multicell Kit with $\mathrm{KBr}$ windows and path length of $1 \mathrm{~mm}$. Molecular modeling calculations were performed by using the Gaussian 09 program package with B3-LYP as functional and def2-SVP as basis set. The structure was geometry optimized, followed by frequency calculation on the optimized structure, which confirmed the existence of a minimum. 


\section{Synthesis and characterization of PBI derivatives}
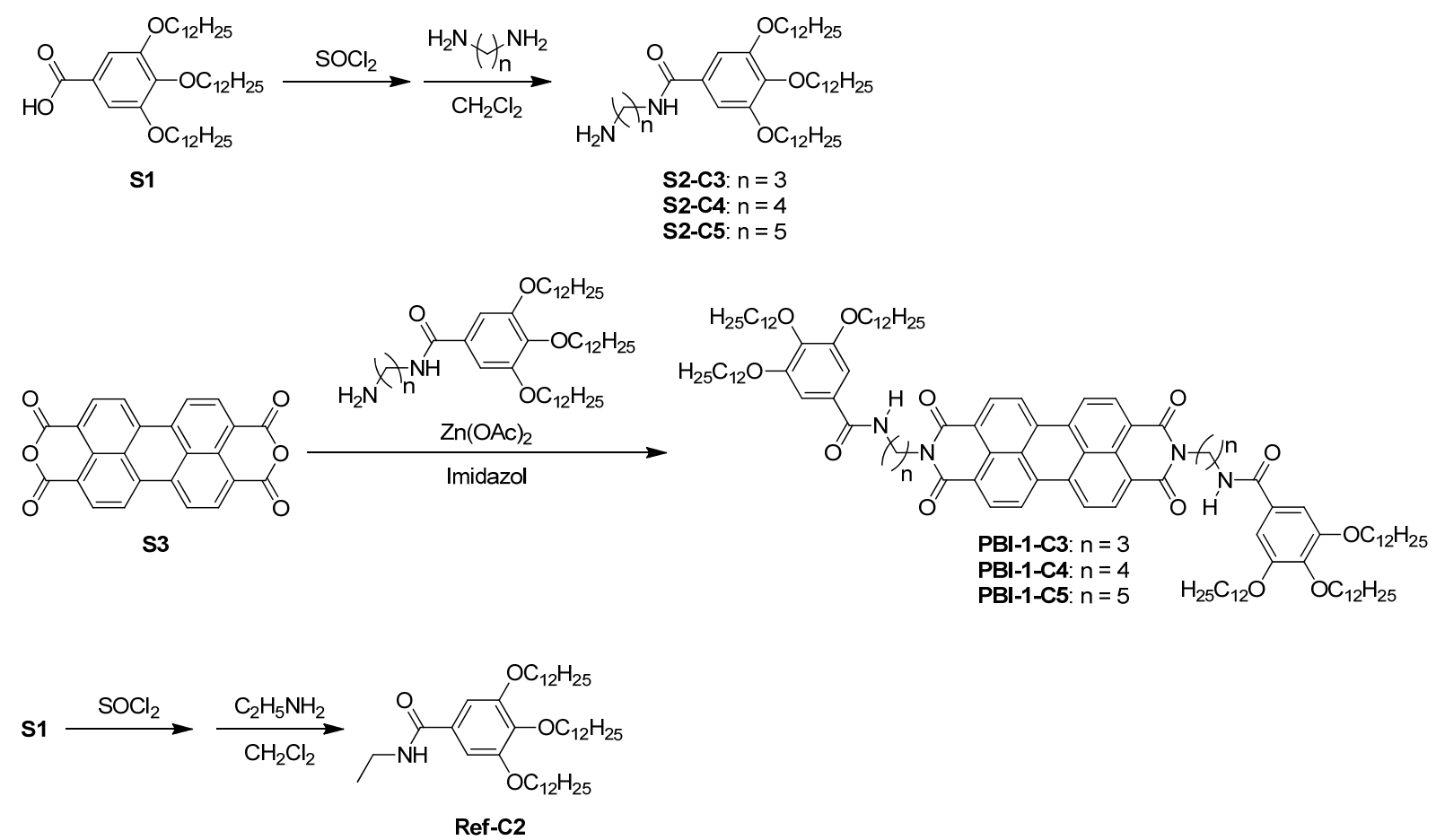

Scheme S1. Synthesis routes of PBI-1-C3, PBI-1-C4, and PBI-1-C5, and the reference benzamide ref-C2.

3,4,5-Tris(dodecyloxy)benzoic acid aminopropylamide (S2-C3): A mixture of benzoic acid stirred at $85{ }^{\circ} \mathrm{C}$ for $2 \mathrm{~h}$ under $\mathrm{N}_{2}$. After the thionyl chloride was distilled at $50{ }^{\circ} \mathrm{C}$ under vacuum, the crude product was obtained as a white solid and it was taken to the next step without further purification. It was redissolved in dry dichloromethane $(5 \mathrm{~mL})$ and the solution was slowly added dropwise to an ice-cold flask containing a solution of 1,3-diaminopropane $(330 \mathrm{mg}, 4.44 \mathrm{mmol})$ in dry dichloromethane $(10 \mathrm{~mL})$. The reaction mixture was stirred in the same ice bath for another $1 \mathrm{~h}$. Then the solvent was evaporated in 
the presence of $\mathrm{SiO}_{2}(15 \mathrm{~g})$. The solid residue was purified through column chromatography $\left(\mathrm{SiO}_{2} ; \mathrm{DCM} / \mathrm{MeOH}, 85: 15\right.$ in volume; $\left.\phi 3 \mathrm{~cm} \times 6 \mathrm{~cm}\right)$ to yield $\mathbf{S 2}-\mathbf{C} 3$ as a light yellow solid $(97 \%)$.

${ }^{1} \mathrm{H}$ NMR (400 MHz, $\left.\mathrm{CDCl}_{3}, 300 \mathrm{~K}\right): \delta=7.55$ (t, $\left.1 \mathrm{H}, J=5.1 \mathrm{~Hz}, \mathrm{NH}\right), 6.99(\mathrm{~s}, 2 \mathrm{H}, \mathrm{Ar}-\mathrm{H})$, 4.04-3.91 (m, 6H, Ar- $\left.\mathrm{OCH}_{2}\right), 3.59-3.50\left(\mathrm{~m}, 2 \mathrm{H}, \mathrm{CH}_{2}\right), 2.90\left(\mathrm{t}, 2 \mathrm{H}, J=6.0 \mathrm{~Hz}, \mathrm{CH}_{2}\right), 1.84-$ $1.67\left(\mathrm{~m}, 8 \mathrm{H}, \mathrm{CH}_{2}\right), 1.51-1.39\left(\mathrm{~m}, 6 \mathrm{H}, \mathrm{CH}_{2}\right), 1.39-1.16\left(\mathrm{~m}, 50 \mathrm{H}, \mathrm{CH}_{2}\right), 0.87$ (t, 9H, $J=6.9 \mathrm{~Hz}$, $\left.\mathrm{CH}_{3}\right) ;{ }^{13} \mathrm{C} \mathrm{NMR}\left(100 \mathrm{MHz}, \mathrm{CDCl}_{3}, 300 \mathrm{~K}\right): \delta=167.17,152.93,140.84,129.64,105.61,73.44$, $69.22,40.73,39.33,31.91,31.90,31.45,30.27,29.72,29.71,29.70,29.68,29.63,29.62$, 29.56, 29.38, 29.37, 29.34, 29.32, 26.06, 22.66, 14.09, 0.98; HRMS (ESI): $\mathrm{m} / \mathrm{z}$ calcd for $\mathrm{C}_{46} \mathrm{H}_{87} \mathrm{~N}_{2} \mathrm{O}_{4}[\mathrm{M}+\mathrm{H}]^{+}:$731.6666; found: 731.6666 .

3,4,5-Tris(dodecyloxy)benzoic acid aminobutylamide (S2-C4): Compound S2-C4 was

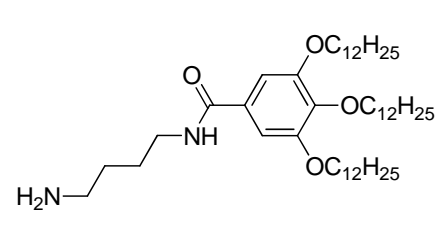
synthesized according to the above-described procedure for compound S2-C3 using benzoic acid derivative S1 (250 mg, 0.37 mmol), thionyl chloride ( $1 \mathrm{~mL}), 1,4$-diaminobutane (260 mg, 2.95

mmol), and dry dichloromethane (15 mL). Light yellow solid (36\%); ${ }^{1} \mathrm{H}$ NMR (400 MHz, $\left.\mathrm{CDCl}_{3}, 300 \mathrm{~K}\right): \delta=6.96(\mathrm{~s}, 2 \mathrm{H}, \mathrm{Ar}-\mathrm{H}), 6.69$ (br, $\left.1 \mathrm{H}, \mathrm{NH}\right), 4.04-3.94\left(\mathrm{~m}, 6 \mathrm{H}, \mathrm{Ar}-\mathrm{OCH}_{2}\right)$, 3.50-3.40 (m, 2H, $\left.\mathrm{CH}_{2}\right), 2.81-2.72\left(\mathrm{~m}, 2 \mathrm{H}, \mathrm{CH}_{2}\right), 1.88-1.16\left(\mathrm{~m}, 64 \mathrm{H}, \mathrm{CH}_{2}\right), 1.16-1.04$ (br, 2H, $\left.\mathrm{NH}_{2}\right), 0.88\left(\mathrm{t}, 9 \mathrm{H}, J=6.9 \mathrm{~Hz}, \mathrm{CH}_{3}\right) ;{ }^{13} \mathrm{C} \mathrm{NMR}\left(100 \mathrm{MHz}, \mathrm{CDCl}_{3}, 300 \mathrm{~K}\right): \delta=167.29,153.01$, $140.96,129.76,105.66,73.47,69.33,41.55,41.43,40.01,39.88,31.93,31.92,30.80,30.76$, $30.29,29.73,29.72,29.69,29.65,29.64,29.58,29.40,29.36,27.07,26.07,22.69,14.12$; HRMS (ESI): $m / z$ calcd for $\mathrm{C}_{47} \mathrm{H}_{89} \mathrm{~N}_{2} \mathrm{O}_{4}[\mathrm{M}+\mathrm{H}]^{+}:$745.6822; found: 745.6819 . 
3,4,5-Tris(dodecyloxy)benzoic acid aminopentylamide (S2-C5): Compound S2-C5 was

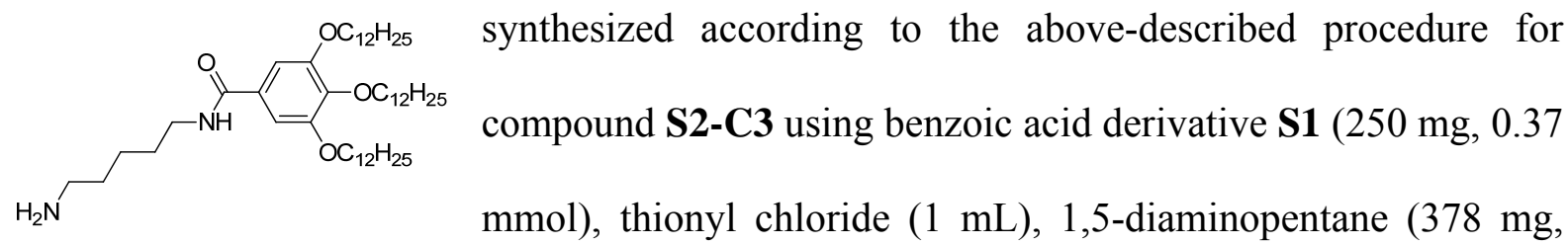

$3.70 \mathrm{mmol})$, and dry dichloromethane (15 mL). Light yellow solid (95\%); ${ }^{1} \mathrm{H}$ NMR (400 MHz, $\left.\mathrm{CDCl}_{3}, 300 \mathrm{~K}\right): \delta=7.22(\mathrm{br}, 1 \mathrm{H}, \mathrm{NH}), 7.05(\mathrm{~s}, 2 \mathrm{H}, \mathrm{Ar}-\mathrm{H}), 4.00-3.84\left(\mathrm{~m}, 6 \mathrm{H}, \mathrm{Ar}-\mathrm{OCH}_{2}\right)$, 3.40-3.26 (m, 2H, $\left.\mathrm{CH}_{2}\right), 2.97\left(\mathrm{~m}, 2 \mathrm{H}, \mathrm{CH}_{2}\right), 1.84-1.65\left(\mathrm{~m}, 8 \mathrm{H}, \mathrm{CH}_{2}\right), 1.65-1.51\left(\mathrm{~m}, 2 \mathrm{H}, \mathrm{CH}_{2}\right)$, 1.51-1.35 (m, 8H, $\left.\mathrm{CH}_{2}\right), 1.35-1.16\left(\mathrm{~m}, 57 \mathrm{H}, \mathrm{CH}_{2}, \mathrm{CH}_{3}\right), 0.87\left(\mathrm{t}, 9 \mathrm{H}, J=6.9 \mathrm{~Hz}, \mathrm{CH}_{3}\right) ;{ }^{13} \mathrm{C}$ NMR (100 MHz, $\left.\mathrm{CDCl}_{3}, 300 \mathrm{~K}\right): \delta=167.57,152.95,140.84,129.03,105.63,73.44,69.17$, $53.40,39.81,31.92,30.35,29.76,29.74,29.69,29.64,29.51,29.38,28.86,27.03,26.17$, 26.10, 23.70, 22.68, 14.09; HRMS (ESI): $m / z$ calcd for $\mathrm{C}_{48} \mathrm{H}_{91} \mathrm{~N}_{2} \mathrm{O}_{4}[\mathrm{M}+\mathrm{H}]^{+}:$759.6979; found: 759.6982 .

3,4,5-Tris(dodecyloxy)benzethylamide (ref-C2): Compound ref-C2 was synthesized

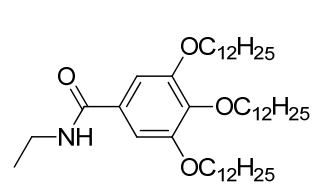
according to the above-described procedure for compound S2-C3 using benzoic acid derivative $\mathbf{S 1}(250 \mathrm{mg}, 0.37 \mathrm{mmol})$, thionyl chloride $(1 \mathrm{~mL})$, $2 \mathrm{M}$ ethylamine in tetrahydrofuran $(280 \mu \mathrm{L})$, and dry dichloromethane $(10$ mL). Light yellow solid (93\%); ${ }^{1} \mathrm{H}$ NMR (400 MHz, $\left.\mathrm{CDCl}_{3}, 300 \mathrm{~K}\right): \delta=6.94$ (s, $\left.2 \mathrm{H}, \mathrm{Ar}-\mathrm{H}\right)$, $5.97(\mathrm{t}, 1 \mathrm{H}, J=5.4 \mathrm{~Hz}, \mathrm{NH}), 4.05-3.94\left(\mathrm{~m}, 6 \mathrm{H}, \mathrm{Ar}-\mathrm{OCH}_{2}\right), 3.53-3.42\left(\mathrm{~m}, 2 \mathrm{H}, \mathrm{CH}_{2}\right), 1.85-$ $1.68\left(\mathrm{~m}, 6 \mathrm{H}, \mathrm{CH}_{2}\right), 1.52-1.40\left(\mathrm{~m}, 6 \mathrm{H}, \mathrm{CH}_{2}\right), 1.40-1.20\left(\mathrm{~m}, 51 \mathrm{H}, \mathrm{CH}_{2}, \mathrm{CH}_{3}\right), 0.88(\mathrm{t}, 9 \mathrm{H}, J=$ $\left.6.9 \mathrm{~Hz}, \mathrm{CH}_{3}\right) ;{ }^{13} \mathrm{C} \mathrm{NMR}\left(100 \mathrm{MHz}, \mathrm{CDCl}_{3}, 300 \mathrm{~K}\right): \delta=167.35,153.05,140.99,129.80$, $105.56,73.48,69.34,34.98,31.93,31.92,30.29,29.73,29.69,29.65,29.63,29.57,29.39$, 29.36, 26.06, 22.69, 14.94, 14.12; HRMS (ESI): $m / z$ calcd for $\mathrm{C}_{45} \mathrm{H}_{84} \mathrm{NO}_{4}[\mathrm{M}+\mathrm{H}]^{+}:$702.6400; found: 702.6397. 


\section{$N, N^{\prime}$-Di[3,4,5-tris(dodecyloxy)benzoylaminoethyl]-perylene-3,4:9,10-tetracarboxylic}

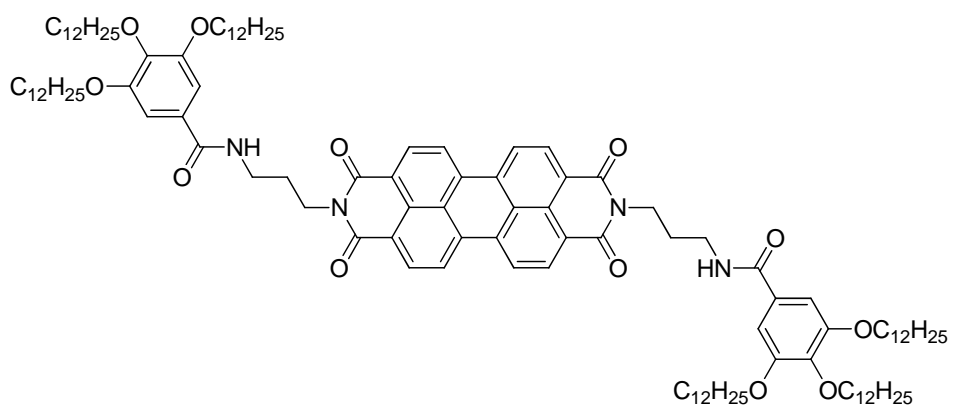

acid bisimide (PBI-1-C3):

Perylene-3,4:9,10-tetracarboxylic

acid bisanhydride (73 $\mathrm{mg}, 0.19$

mmol), benzamide S2-C3 (300 mg, $0.41 \mathrm{mmol})$ and zinc acetate $(137$

$\mathrm{mg}, 0.74 \mathrm{mmol}$ ) were mixed in $3 \mathrm{~g}$ of imidazole. The reaction mixture was stirred at $100{ }^{\circ} \mathrm{C}$ for $6 \mathrm{~h}$. After cooling to room temperature, the mixture was extracted with $\mathrm{CHCl}_{3}(50 \mathrm{~mL})$ and the organic layer was washed with $1 \mathrm{~N} \mathrm{HCl}$ (twice). The filtrate was dried in vacuum and the crude product was purified by preparative $\mathrm{TLC}\left(\mathrm{SiO}_{2} ; \mathrm{CHCl}_{3} /\right.$ aceton, $98: 2$ in volume $)$ to give a red solid $(75 \%)$.

${ }^{1} \mathrm{H}$ NMR (400 MHz, CDCl3, $300 \mathrm{~K}$ ): $\delta=8.74-8.67$ (m, 8H, H-pery), 7.30 (t, 2H, $J=6.1 \mathrm{~Hz}$, $\mathrm{NH}), 7.18(\mathrm{~s}, 4 \mathrm{H}, \mathrm{Ar}-\mathrm{H}), 4.38\left(\mathrm{t}, 4 \mathrm{H}, J=6.1 \mathrm{~Hz}, \mathrm{CH}_{2}\right), 4.10\left(\mathrm{t}, 8 \mathrm{H}, J=6.6 \mathrm{~Hz}, \mathrm{Ar}-\mathrm{OCH}_{2}\right)$, $4.01\left(\mathrm{t}, 4 \mathrm{H}, J=6.5 \mathrm{~Hz}, \operatorname{Ar}-\mathrm{OCH}_{2}\right), 3.48\left(\mathrm{q}, 4 \mathrm{H}, J=5.8 \mathrm{~Hz}, \mathrm{CH}_{2}\right), 2.15-2.09\left(\mathrm{~m}, 4 \mathrm{H}, \mathrm{CH}_{2}\right)$, 1.88-1.72 (m, 12H, $\left.\left.\mathrm{CH}_{2}\right), 1.53-1.14\left(\mathrm{~m}, 108 \mathrm{H}, \mathrm{CH}_{2}\right), 0.91-0.81\left(\mathrm{~m}, 18 \mathrm{H}, \mathrm{CH}_{3}\right) ; \mathrm{HRMS} \mathrm{ESI}\right)$ : $m / z$ calcd for $\mathrm{C}_{116} \mathrm{H}_{177} \mathrm{~N}_{4} \mathrm{O}_{12}[\mathrm{M}+\mathrm{H}]^{+}:$1819.3397; found: 1819.3404 ; elemental analysis (\%) calculated for $\mathrm{C}_{116} \mathrm{H}_{176} \mathrm{~N}_{4} \mathrm{O}_{12}$ (1818.7): C 76.61, H 9.75, N 3.08; found: $\mathrm{C} 76.23, \mathrm{H} 9.62, \mathrm{~N}$ 2.82

$N, N^{\prime}$-Di[3,4,5-tris(dodecyloxy)benzoylaminopropyl]-perylene-3,4:9,10-tetracarboxylic

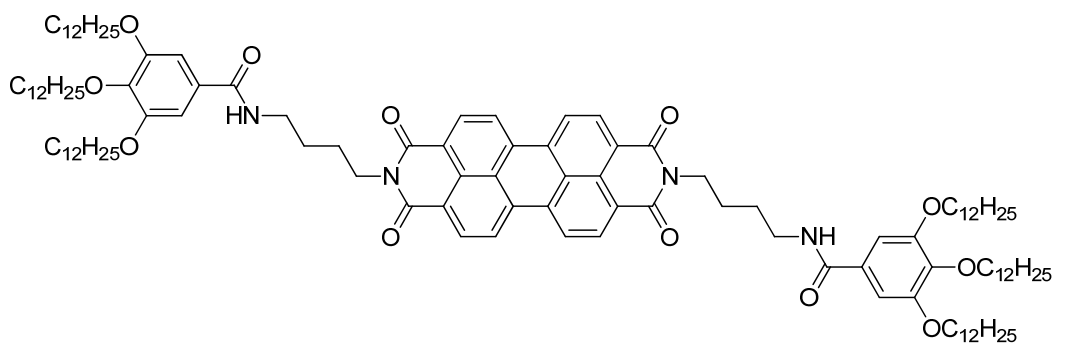
acid bisimide (PBI-1-C4): Compound PBI-1-C4 was synthesized according to the above-described procedure

for compound PBI-1-C3 using perylene-3,4:9,10-tetracarboxylic acid bisanhydride (23 mg, 
$0.06 \mathrm{mmol})$, benzamide S2-C4 $(96 \mathrm{mg}, 0.13 \mathrm{mmol})$, zinc acetate (43 $\mathrm{mg}, 0.23 \mathrm{mmol})$, and imidazole (2 g). Red solid (76\%); ${ }^{1} \mathrm{H}$ NMR (400 MHz, $\left.\mathrm{CDCl}_{3}, 300 \mathrm{~K}\right): \delta=8.65(\mathrm{~d}, 4 \mathrm{H}, J=$ $8.0 \mathrm{~Hz}, \mathrm{H}$-pery), 8.58 (d, 4H, $J=8.2 \mathrm{~Hz}, \mathrm{H}$-pery), 7.04 (s, 4H, Ar-H), 6.57 (t, 2H, $J=5.7 \mathrm{~Hz}$, $\mathrm{NH}), 4.26\left(\mathrm{t}, 4 \mathrm{H}, J=7.2 \mathrm{~Hz}, \mathrm{CH}_{2}\right), 4.06-3.92\left(\mathrm{~m}, 12 \mathrm{H}, \mathrm{Ar}-\mathrm{OCH}_{2}\right), 3.58$ (q, 4H, $J=6.4 \mathrm{~Hz}$, $\left.\mathrm{CH}_{2}\right), 1.97-1.85\left(\mathrm{~m}, 4 \mathrm{H}, \mathrm{CH}_{2}\right), 1.85-1.67\left(\mathrm{~m}, 16 \mathrm{H}, \mathrm{CH}_{2}\right), 1.50-1.38\left(\mathrm{~m}, 12 \mathrm{H}, \mathrm{CH}_{2}\right), 1.35-1.19$ (m, $\left.96 \mathrm{H}, \mathrm{CH}_{2}\right), 0.92-0.81\left(\mathrm{~m}, 18 \mathrm{H}, \mathrm{CH}_{3}\right)$; HRMS (ESI): $m / z$ calcd for $\mathrm{C}_{118} \mathrm{H}_{181} \mathrm{~N}_{4} \mathrm{O}_{12}[\mathrm{M}+\mathrm{H}]^{+}$: 1847.3710; found: 1847.3690 .

\section{$N, N$ '-Di[3,4,5-tris(dodecyloxy)benzoylaminobutyl]-perylene-3,4:9,10-tetracarboxylic}

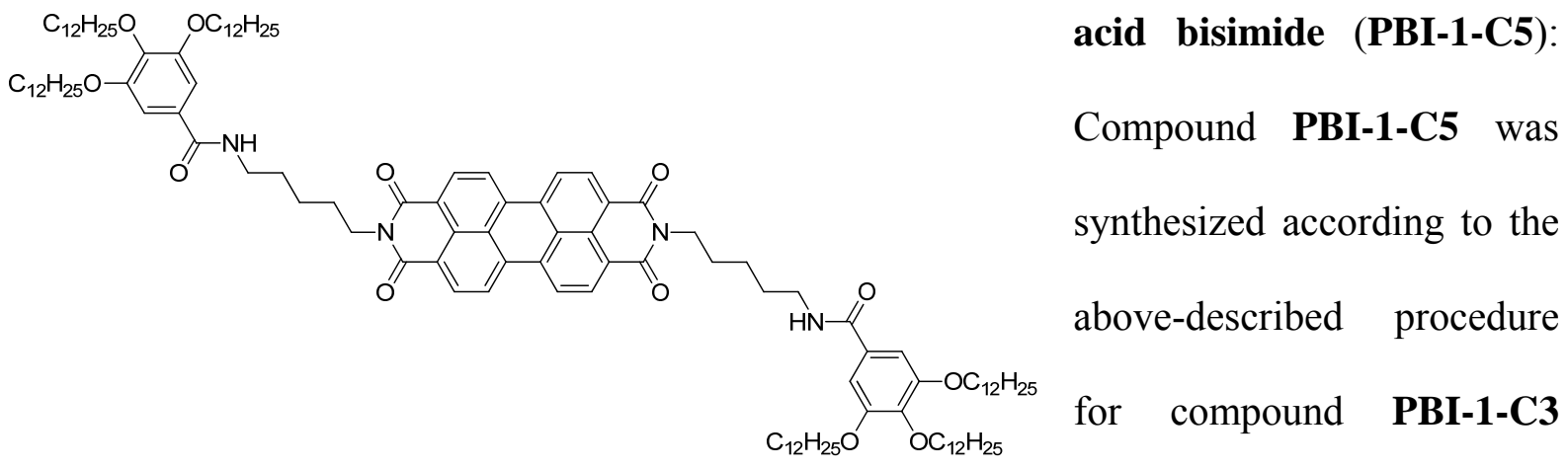

using perylene-3,4:9,10-tetracarboxylic acid bisanhydride (35 $\mathrm{mg}, 0.09 \mathrm{mmol}$ ), benzamide S2-C5 (150 mg, $0.20 \mathrm{mmol})$, zinc acetate $(66 \mathrm{mg}, 0.36 \mathrm{mmol})$, and imidazole $(3 \mathrm{~g})$. Red solid (75\%); ${ }^{1} \mathrm{H}$ NMR (400 MHz, $\left.\mathrm{CDCl}_{3}, 300 \mathrm{~K}\right): \delta=8.64-8.51$ (m, 8H, H-pery), 6.95 (s, 4H, ArH), $6.24(\mathrm{t}, 2 \mathrm{H}, J=5.5 \mathrm{~Hz}, \mathrm{NH}), 4.25\left(\mathrm{t}, 4 \mathrm{H}, J=7.1 \mathrm{~Hz}, \mathrm{CH}_{2}\right), 4.03-3.93\left(\mathrm{~m}, 12 \mathrm{H}, \mathrm{Ar}-\mathrm{OCH}_{2}\right)$, $3.48\left(\mathrm{q}, 4 \mathrm{H}, J=6.3 \mathrm{~Hz}, \mathrm{CH}_{2}\right), 1.90-1.70\left(\mathrm{~m}, 20 \mathrm{H}, \mathrm{CH}_{2}\right), 1.53-1.18\left(\mathrm{~m}, 112 \mathrm{H}, \mathrm{CH}_{2}\right), 0.90-0.84$ (m, 18H, $\mathrm{CH}_{3}$ ); HRMS (ESI): $m / z$ calcd for $\mathrm{C}_{120} \mathrm{H}_{185} \mathrm{~N}_{4} \mathrm{O}_{12}[\mathrm{M}+\mathrm{H}]^{+}$: 1875.4023; found: 1875.4008 . 


\section{3. ${ }^{1} \mathrm{H}$ NMR spectra of monomeric ref-C2 and PBI-1-C4}

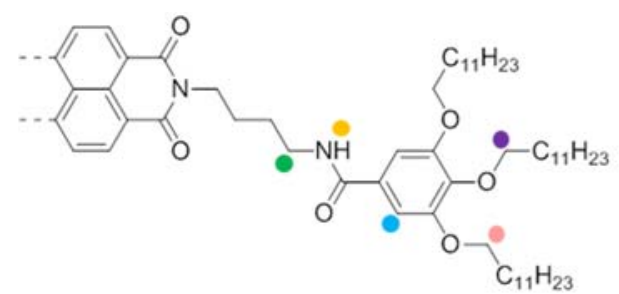

PBI-1-C4

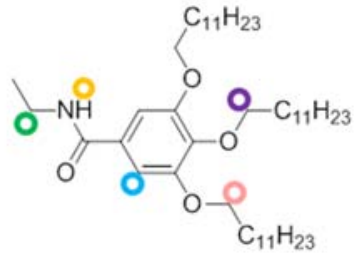

Ref-C2
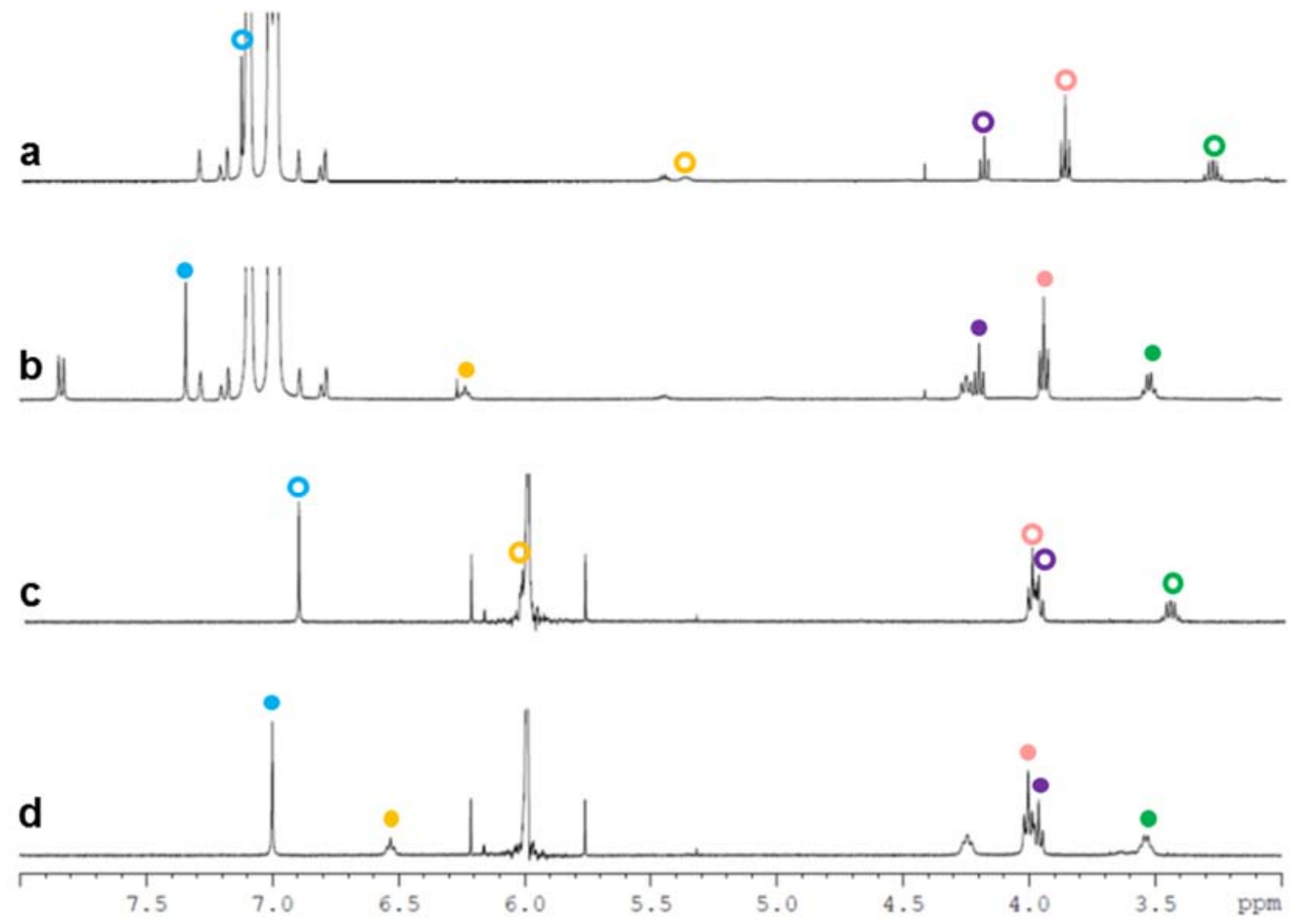

Figure S1. Partial ${ }^{1} \mathrm{H}$ NMR spectra of (a) ref-C2 and (b) PBI-1-C4 in toluene- $d_{8}\left(c_{\mathrm{T}}=2.5 \times\right.$ $\left.10^{-4} \mathrm{M}, 338 \mathrm{~K}\right)$ and (c) ref-C2 and (d) PBI-1-C4 in 1,1,2,2-tetrachloroethane- $d_{2}\left(c_{\mathrm{T}}=5 \times\right.$ $\left.10^{-4} \mathrm{M}, 298 \mathrm{~K}\right)$. Chemical shifts of each proton peak are provided in the Supporting Information Tables S1 and S2.

Interpretation: In 1,1,2,2-tetrachloroethane- $d_{2}$ the amide $\mathrm{N}-\mathrm{H}$ proton peak of monomeric PBI1-C4 was observed at $6.53 \mathrm{ppm}$, which is downfield-shifted by $0.52 \mathrm{ppm}$ compared with that of ref-C2. This downfield shift is rationalized by a small fraction of intramolecularly hydrogen-bonded molecules. In less polar toluene- $d_{8}$ this fraction is increased and accordingly the difference in the chemical shift $(\Delta \delta)$ of the amide $\mathrm{N}-\mathrm{H}$ proton becomes larger $(0.88 \mathrm{ppm})$. Additionally, downfield shifts are observable for proton peaks of the butylene spacer and trialkoxyphenyl group in particular in toluene- $d 8$. These downfield shifts can also be 
rationalized by the formation of intramolecular hydrogen bonds between the amide hydrogens and imide carbonyl oxygens, leading to a conformation (see Supporting Information Figure S2c) where the ring current effect of the PBI is exerted on the butylene and trialkoxyphenyl protons.

Table S1. Chemical shifts of amide N-H proton and trialkoxyphenyl protons of PBI-1-C4 and ref-C2 in 1,1,2,2-tetrachloroethane- $d_{2}\left(c_{\mathrm{T}}=5 \times 10^{-4} \mathrm{M}, 298 \mathrm{~K}\right)$ and the difference in the chemical shift $(\Delta \delta)$ of each proton peak of PBI-1-C4 and ref-C2.

\begin{tabular}{cccc}
\hline & $\begin{array}{c}\text { Chemical shifts of } \\
\text { PBI-1-C4 }(\mathrm{ppm})\end{array}$ & $\begin{array}{c}\text { Chemical shifts of } \\
\text { ref-C2 }(\mathrm{ppm})\end{array}$ & $\Delta \delta(\mathrm{ppm})$ \\
\hline amide $\mathrm{N}-H$ & 6.53 & 6.01 & 0.52 \\
$\mathrm{OCH}_{2}$ (p-position) & 3.96 & 3.96 & 0 \\
$\mathrm{OCH}_{2}$ (o-position) & 4.00 & 3.99 & 0.01 \\
Phenyl proton & 7.00 & 6.90 & 0.10 \\
$\mathrm{C} H_{2} \mathrm{NH}$ & 3.54 & 3.44 & 0.10 \\
\hline
\end{tabular}

Table S2. Chemical shifts of amide N-H proton and trialkoxyphenyl protons of PBI-1-C4 and ref-C2 in toluene- $d_{8}\left(c_{\mathrm{T}}=2.5 \times 10^{-4} \mathrm{M}, 338 \mathrm{~K}\right)$ and the difference in the chemical shift $(\Delta \delta)$ of each proton peak of PBI-1-C4 and ref-C2.

\begin{tabular}{cccc}
\hline & $\begin{array}{c}\text { Chemical shifts of } \\
\text { PBI-1-C4 }(\mathrm{ppm})\end{array}$ & $\begin{array}{c}\text { Chemical shifts of } \\
\text { ref-C2 }(\mathrm{ppm})\end{array}$ & $\Delta \delta$ (ppm) \\
\hline amide $\mathrm{N}-\mathrm{H}$ & 6.24 & 5.36 & 0.88 \\
$\mathrm{OCH} \mathrm{H}_{2}$ (p-position) & 4.20 & 4.18 & 0.02 \\
$\mathrm{OCH}_{2}$ (o-position) & 3.94 & 3.86 & 0.08 \\
Phenyl proton & 7.34 & 7.12 & 0.22 \\
$\mathrm{C} H_{2} \mathrm{NH}$ & 3.52 & 3.27 & 0.25 \\
\hline
\end{tabular}




\section{Energy minimized structures of PBI derivatives}

top view

a

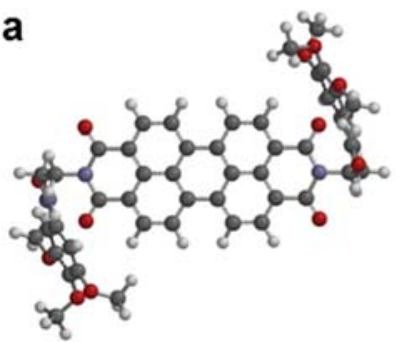

b
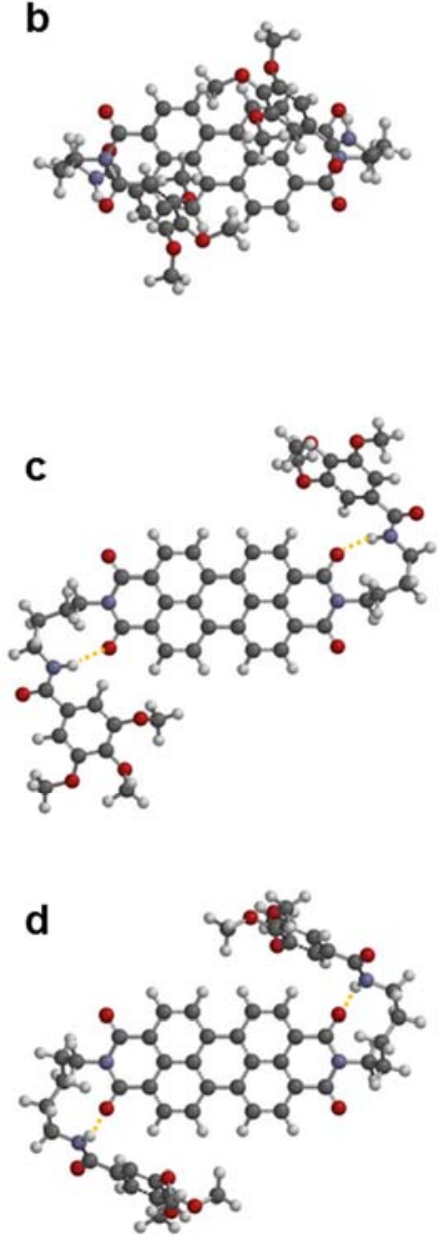

front view
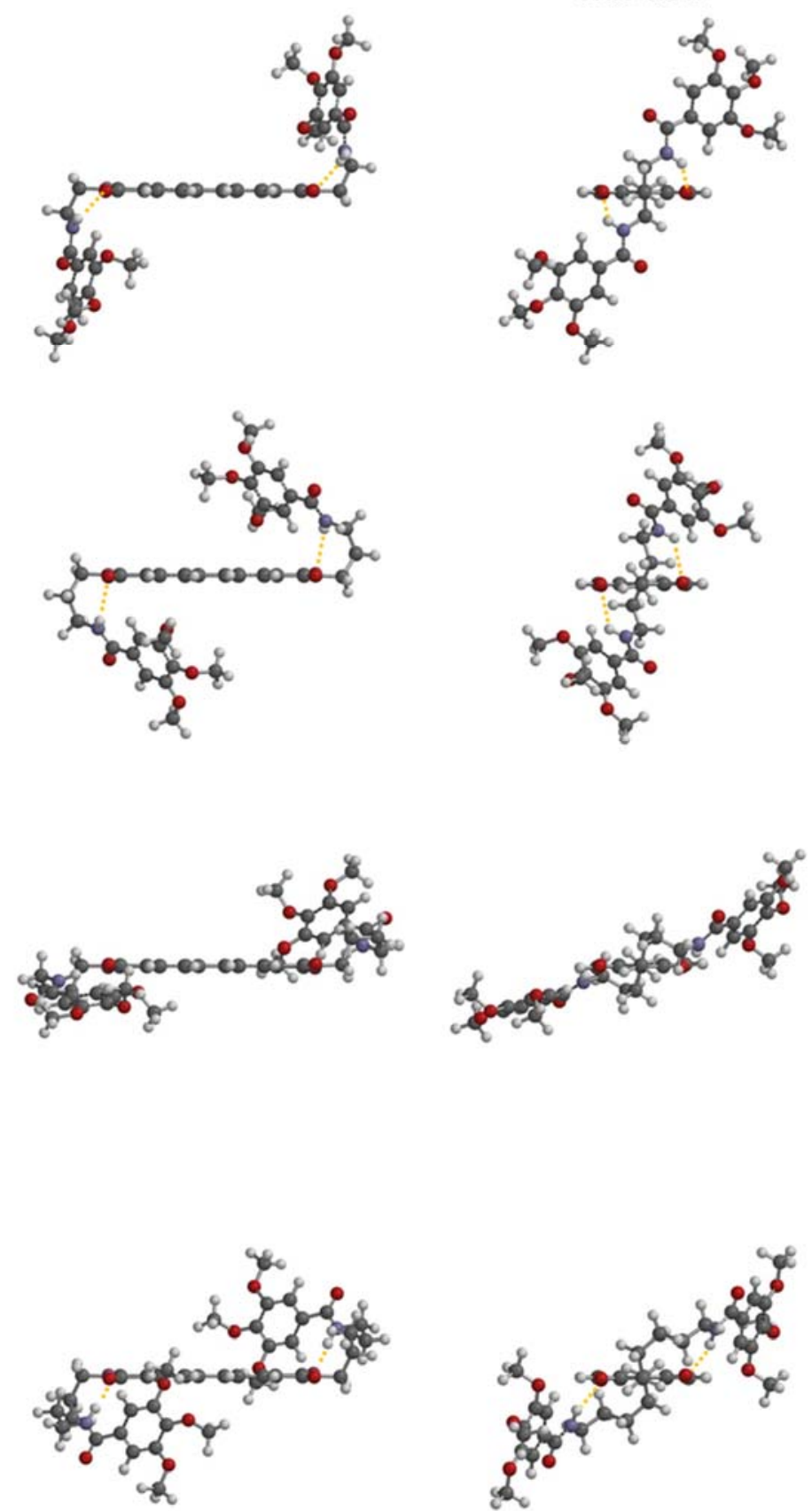
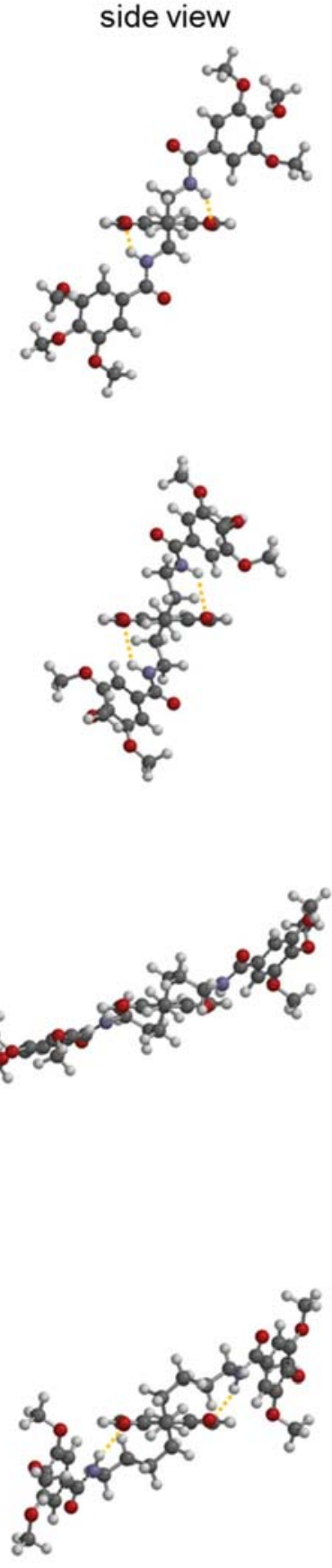

Figure S2. (a-d) Energy minimized structures obtained from DFT calculations (Gaussian 09 program package with B3-LYP as functional and def2-SVP as basis set) of (a) PBI-1-C2, (b) PBI-1-C3, (c) PBI-1-C4, and (d) PBI-1-C5. Trisdodecyloxy groups are replaced by trimethoxy groups for simplicity. The dashed orange lines represent intramolecular hydrogen bonds. 


\section{Analysis of self-assembly behavior of PBI-1-C4}

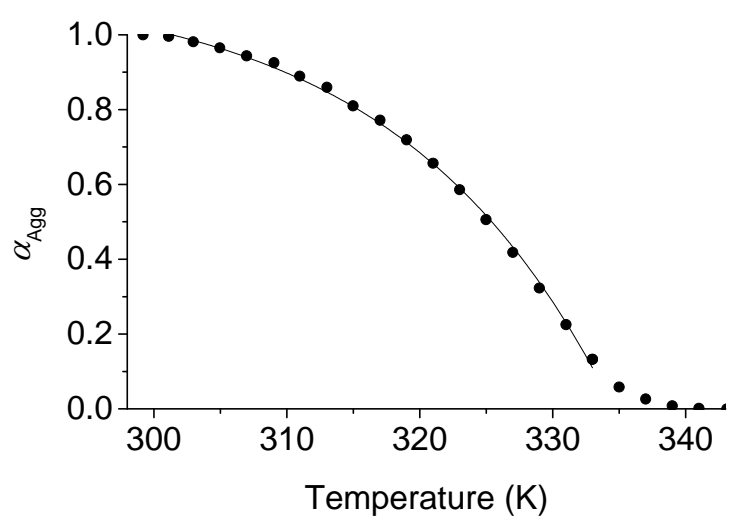

Figure S3. Temperature-dependent degree of aggregation $\left(\alpha_{\mathrm{Agg}}\right)$ for PBI-1-C4 $4_{\mathrm{Agg} 1}$ calculated from the apparent absorption coefficients at $\lambda=523 \mathrm{~nm}$ at a total concentration of $c_{\mathrm{T}}=5 \times$ $10^{-6} \mathrm{M}$ in $\mathrm{MCH} /$ toluene $(2: 1, \mathrm{v} / \mathrm{v})$. The curve shows the resulting fit of the elongation regime calculated according to the cooperative model proposed by Meijer and co-workers. ${ }^{\mathrm{S} 2, \mathrm{~S} 3}$

a

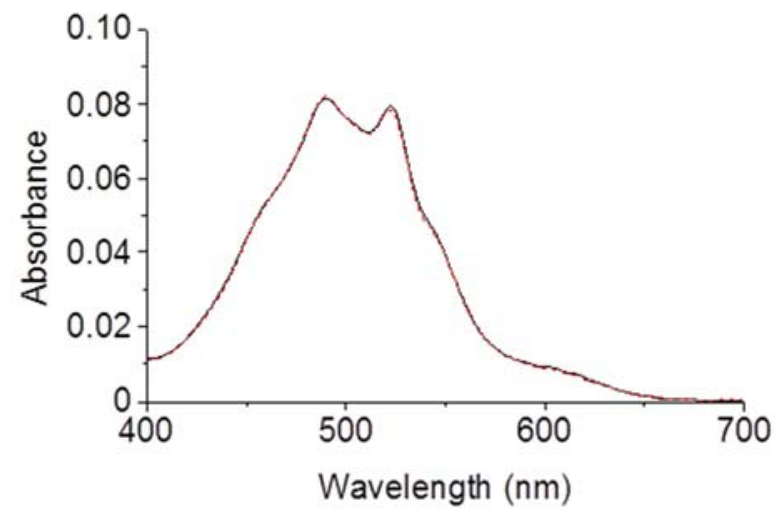

b

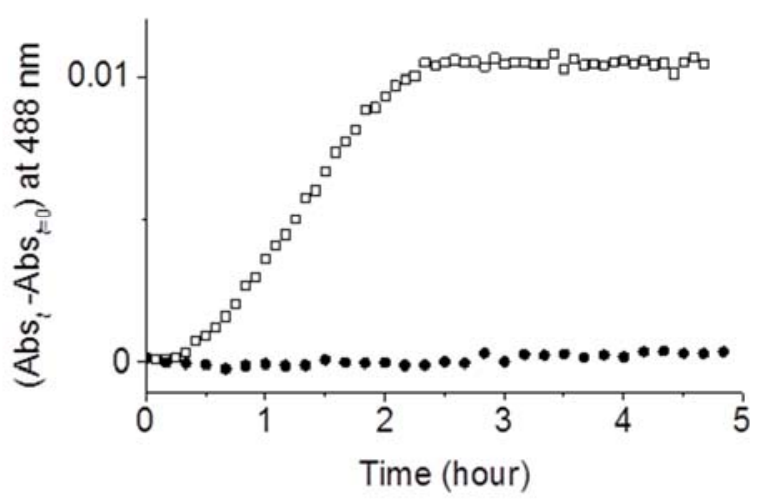

Figure S4. (a) Absorption spectra of an unstirred solution of PBI-1-C4 $\mathbf{A g g}_{\text {in1 }}$ in $\mathrm{MCH} /$ toluene $(2: 1, \mathrm{v} / \mathrm{v})$ observed 0 (black solid line) and $5 \mathrm{~h}$ (red dotted line) after rapid cooling from 353 to $308 \mathrm{~K}$. Conditions: $c_{\mathrm{T}}=5 \times 10^{-6} \mathrm{M}, 308 \mathrm{~K}$. (b) Time-dependent absorbance changes at 488 $\mathrm{nm}$ of the unstirred solution (closed circles) observed in Figure S4a and the solution under stirring at a rate of $400 \mathrm{rpm}$ (open squares) observed in Figure 5a. 

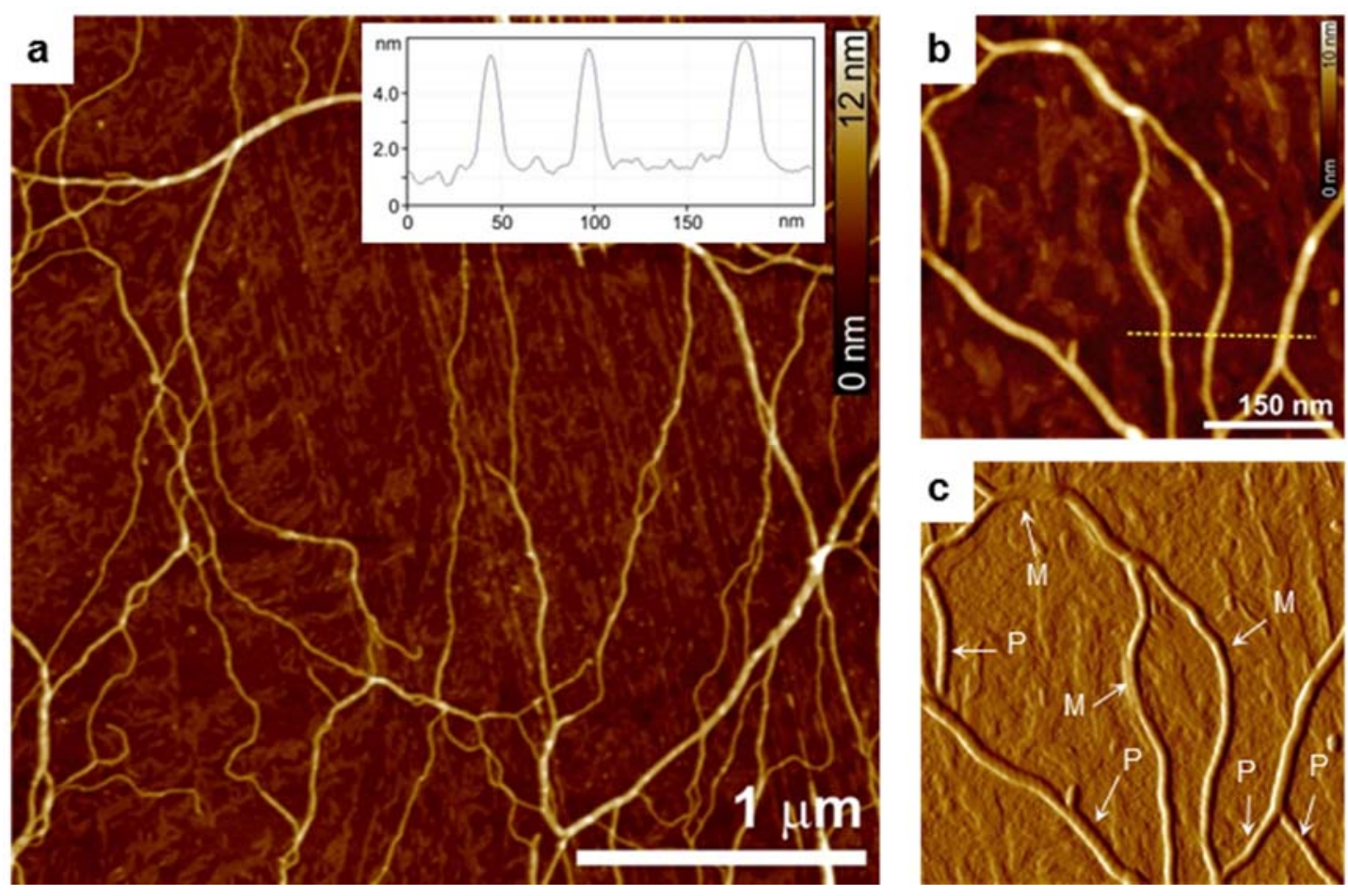

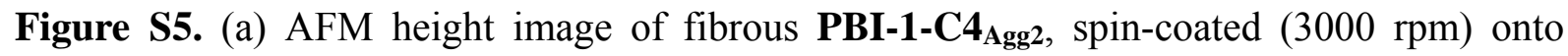
silicon substrate from a solution in $\mathrm{MCH} /$ toluene $(2: 1, \mathrm{a} v / v)$. (b) Zoomed height and (c) phase

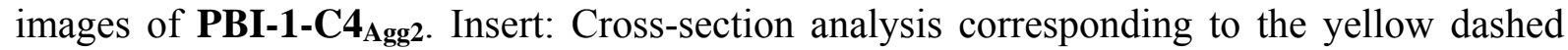
line in Figure S5b. 


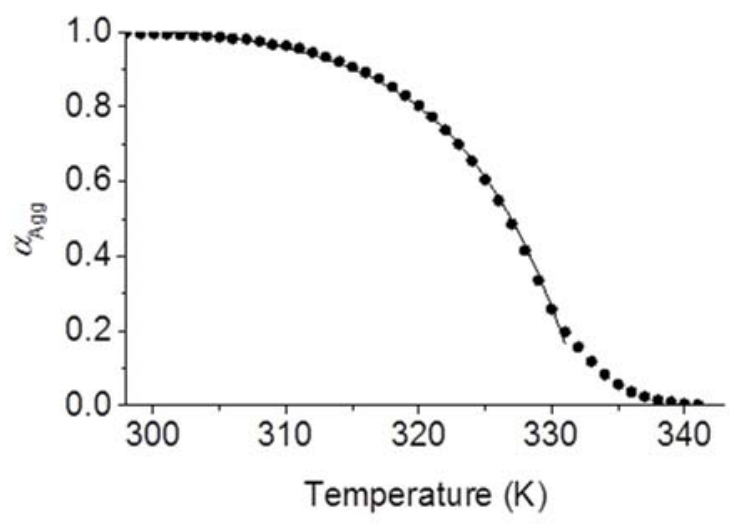

Figure S6. Temperature-dependent degree of aggregation $\left(\alpha_{\mathrm{Agg}}\right)$ calculated from the apparent absorption coefficients at $\lambda=523 \mathrm{~nm}$ observed upon heating the solution of PBI-1-C4 $\mathbf{A g g}_{\text {ag }}$ at a total concentration of $c_{\mathrm{T}}=5 \times 10^{-6} \mathrm{M}$ in $\mathrm{MCH} /$ toluene $(2: 1, \mathrm{v} / \mathrm{v})$. The curve shows the resulting fit of the elongation regime calculated according to the cooperative model proposed by Meijer and co-workers. ${ }^{\text {S2,S3 }}$

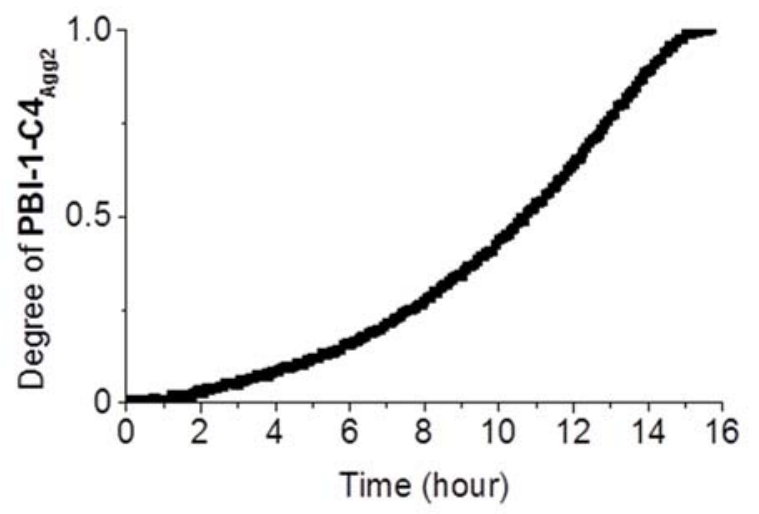

Figure S7. Time-dependent degree of PBI-1-C4 $\mathbf{A g g}_{\mathbf{A g} 2}$ calculated from the apparent absorption coefficients at $\lambda=488 \mathrm{~nm}$ observed in the transformation process from PBI-1-C4 $4_{\text {Agg1 }}$ to PBI1-C4 $4_{\mathrm{Agg} 2}$ in $(S)$-limonene at a concentration of $c_{\mathrm{T}}=2 \times 10^{-5} \mathrm{M}$ and a temperature of $298 \mathrm{~K}$ under stirring at a rate of $400 \mathrm{rpm}$. 


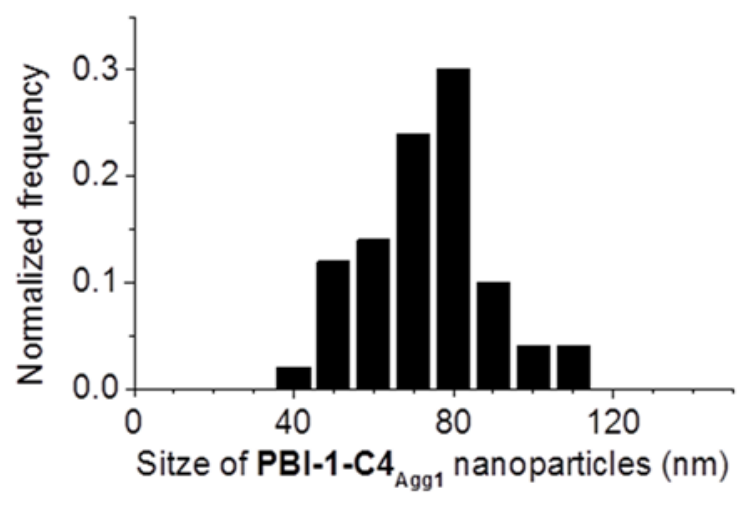

Figure S8. Histogram of the size distribution of the nanoparticle-shaped PBI-1-C4 Agg1 obtained by tracing 50 objects in the SEM image shown in Figure 8a.

Table S3. Morphological parameters of the nanoparticle-shaped PBI-1-C4 $\mathbf{A g g 1}_{\mathrm{A} 1}$ and fibrous

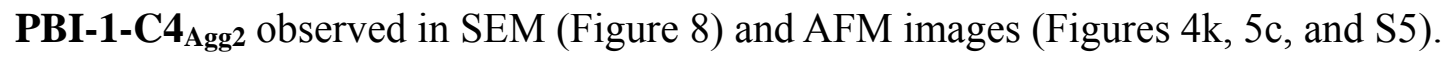

\begin{tabular}{|c|c|c|}
\hline & $\begin{array}{l}\text { SEM sample } \\
\left.\text { (cyclohexane, } 1 \times 10^{-3} \mathrm{M}\right)\end{array}$ & $\begin{array}{l}\text { AFM sample } \\
\left(\mathrm{MCH} / \text { toluene }(2: 1, \mathrm{v} / \mathrm{v}), 5 \times 10^{-6} \mathrm{M}\right)\end{array}$ \\
\hline $\begin{array}{l}\text { PBI-1-C4 } 4_{\text {Agg1 }} \\
\text { (Nanoparticles) }\end{array}$ & Size: $40-110 \mathrm{~nm}$ & Height: $2-8 \mathrm{~nm}$ \\
\hline$\overline{\text { PBI-1-C4 }}{ }_{\text {Agg2 }}$ & Length: several micrometers & Length: several micrometers \\
\hline $\begin{array}{l}\text { (Supramolecular } \\
\text { polymers) }\end{array}$ & $\begin{array}{l}\text { Width: } 20-130 \mathrm{~nm} \text { (agglomeration } \\
\text { of fibers) }\end{array}$ & $\begin{array}{l}\text { Width: from } 4 \mathrm{~nm} \text { (single fibers) up to } \\
50 \mathrm{~nm} \text { (agglomeration of fibers) }\end{array}$ \\
\hline
\end{tabular}


a

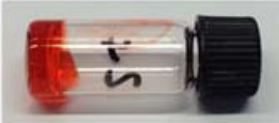

$\mathrm{PBI}-1-\mathrm{C} 2$ in cyclohexane
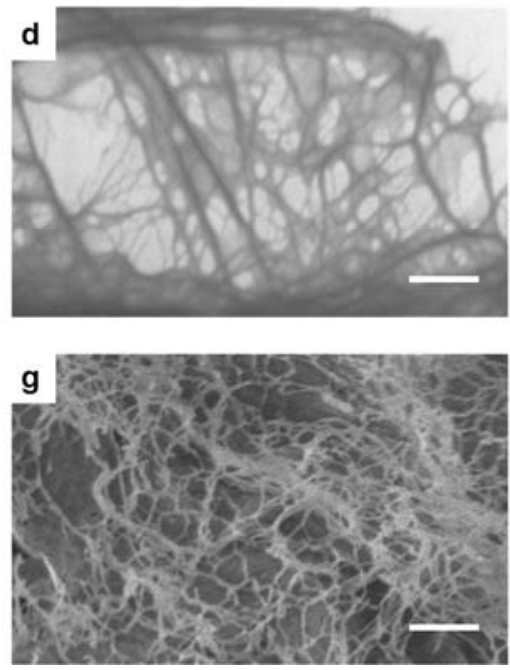

b

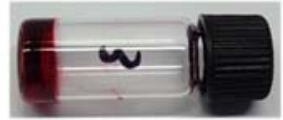

$\mathrm{PBI}-1-\mathrm{C} 3$ in cyclohexane
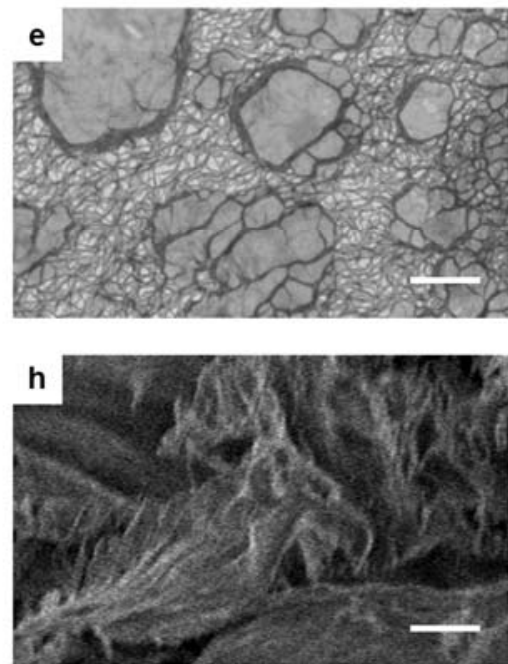

c

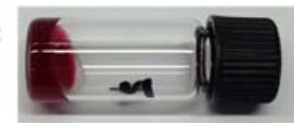

PBI-1-C5 in cyclohexane
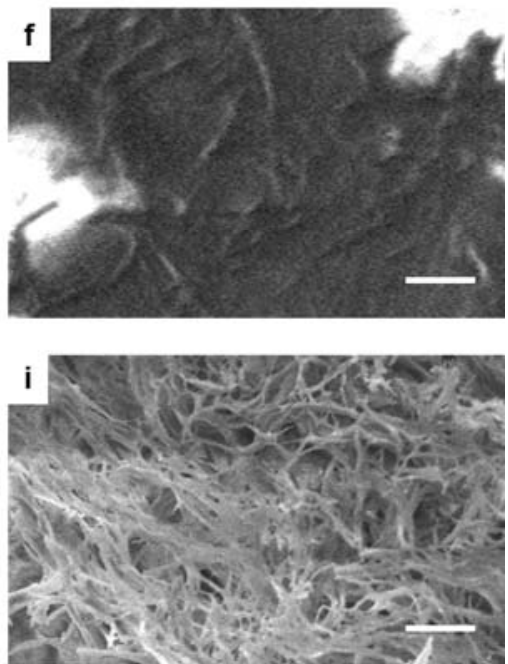

Figure S9. (a-c) Photographs of samples of PBI-1-C2 (a), PBI-1-C3 (b), and PBI-1-C5 (c) in cyclohexane $\left(c_{\mathrm{T}}=1 \times 10^{-3} \mathrm{M}\right)$ obtained 1 day after cooling to room temperature. (d-i) SEM images of drop-casted (d-f) and freeze-dried aggregates (g-i) of PBI-1-C2 (d,g), PBI-1-C3 (e,h), and PBI-1-C5 (f,i) on silicon wafers prepared from the samples of each PBIs in cyclohexane. Scale bar, $2 \mu \mathrm{m}$. 


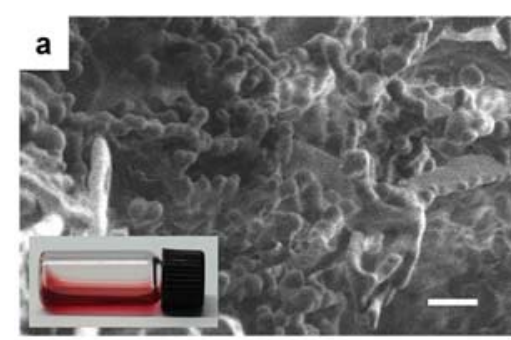

quick after cooling to room temperature

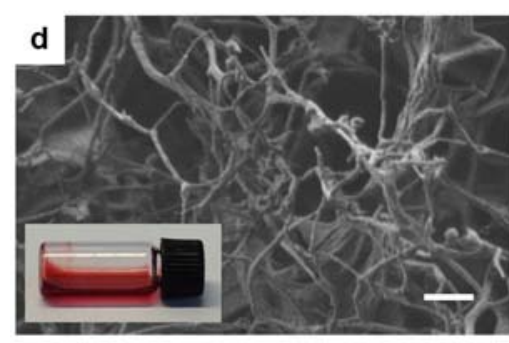

3 days after

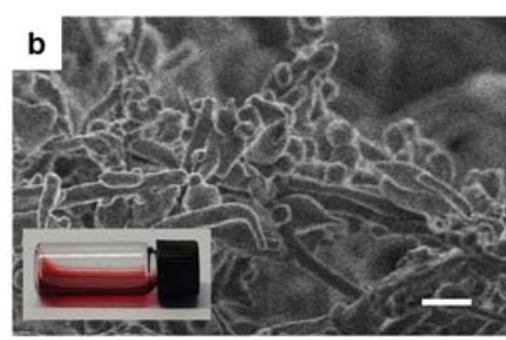

1 day after

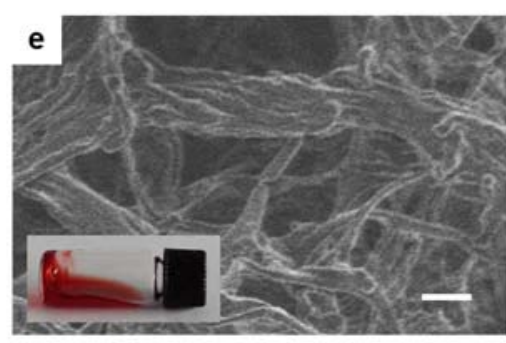

4 days after

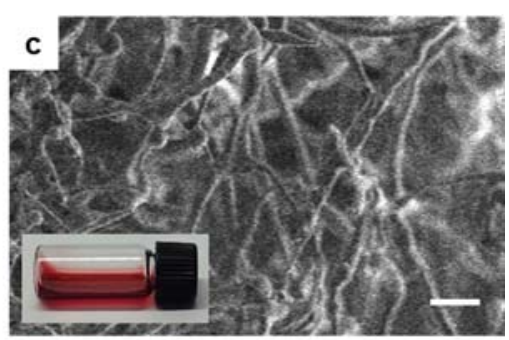

2 days after

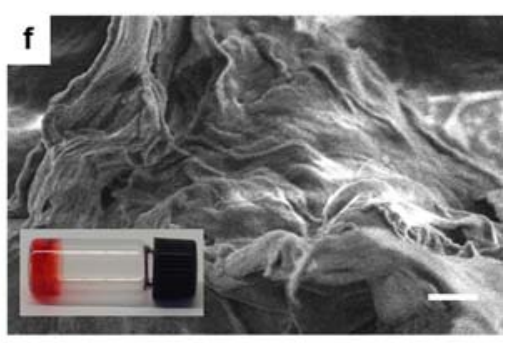

5 days after

Figure S10. (a-f) SEM images of freeze-dried aggregates of PBI-1-C4 on silicon wafers prepared from the samples of each cyclohexane solutions $\left(c_{\mathrm{T}}=1 \times 10^{-3} \mathrm{M}\right)$ obtained freshly (a), 1 day (b), 2 days (c), 3 days (d), 4 days (e), and 5 days (f) after cooling to room temperature. Scale bar, $2 \mu \mathrm{m}$. Inserts: Photographs of solution and gel samples.

\section{References}

S1) Tang, Y.; Zhou, L.; Li, J.; Luo, Q.; Huang, X.; Wu, P.; Wang, Y.; Xu, J.; Shen, J.; Liu, J. Angew. Chem. Int. Ed. 2010, 49, 3920-3924.

S2) Jonkheijm, P.; van der Schoot, P.; Schenning, A. P. H. J.; Meijer, E. W. Science 2006, $313,80-83$.

S3) Smulders, M. M. J.; Schenning, A. P. H. J.; Meijer E. W. J. Am. Chem. Soc. 2008, 130, $606-611$. 